\title{
Surfactant improves lung function and mitigates bacterial growth in immature ventilated rabbits with experimentally induced neonatal group B streptococcal pneumonia
}

Egbert Herting, Bo Sun, Connie Jarstrand, Tore Curstedt, Bengt Robertson

Department of

Paediatrics,

University of

Göttingen, Germany

E Herting

Division For

Experimental

Perinatal Pathology,

Department of Woman

and Child Health,

Karolinska Institute,

Stockholm, Sweden

E Herting

B Sun

B Robertson

Department of Clinical Bacteriology,

Karolinska Institute,

Huddinge Hospital,

Stockholm, Sweden

C Jarstrand

Department of Clinical

Chemistry,

Karolinska Institute,

Danderyd Hospital,

Stockholm, Sweden

T Curstedt

Correspondence to: Dr Egbert Herting,

Department of Paediatrics,

University of Göttingen,

Robert-Koch Str. 40,

D-37075 Göttingen,

Germany.

Accepted

19 September 1996

\begin{abstract}
Aims-To study the influence of surfactant on lung function and bacterial proliferation in immature newborn rabbits with experimental group B streptococcal (GBS) pneumonia.

Methods-Preterm rabbit fetuses (gestational age 28 days) underwent tracheotomy and were mechanically ventilated in a warmed body plethysmograph that permitted measurement of lung-thorax compliance. Fifteen minutes after the onset of ventilation the animals received either GBS or saline intratracheally; at 30 minutes, a bolus of saline or $200 \mathrm{mg} / \mathrm{kg}$ of a porcine surfactant (Curosurf) was administered via the airway. Bacterial proliferation was evaluated in lung homogenate at the end of the experiments and the results expressed as mean $\log _{10}$ cfu/g lung (SD). Animals receiving only saline $(n=20)$ or saline and surfactant $(n=20)$ served as controls.

Results-The average survival time was about three hours in all groups. Infected animals receiving surfactant $(n=22)$ had significantly less bacterial growth (9.09 (0.45) vs $9.76(0.91)$ ) and improved lung function (compliance: $0.61(0.14)$ vs 0.34 $(0.19) \mathrm{ml} / \mathrm{kg}$. $\left.\mathrm{cm} \mathrm{H}_{2} \mathrm{O}\right)$ than infected $\mathrm{rab}-$ bits receiving saline at 30 minutes $(n=22)$. Conclusion-Surfactant improves lung function and mitigates bacterial growth in preterm rabbits infected with group B streptococci.

(Arch Dis Child 1997;76:F3-F8)
\end{abstract}

Keywords: surfactant; rabbits; group B streptococci; lung function; bacterial growth.

Group B streptococci (GBS) cause considerable mortality and morbidity in the neonatal period. Vaginal colonisation with this organism is common during pregnancy. ${ }^{1}$ One to four in every thousand newborn infants has early onset GBS septicaemia. The incidence is higher in premature newborn babies and although only a few term newborn infants die from the disease nowadays, there is a disturbingly high mortality in premature babies with GBS infections. ${ }^{12}$

Most premature infants with systemic or pulmonary GBS infections have respiratory symptoms. ${ }^{2}{ }^{3}$ Thus many of these infants are likely to be given surfactant treatment before the final diagnosis is established. There has been considerable concern that surfactant treatment might actually harm these infants, as previous animal studies have shown an increased bacterial growth following surfactant treatment in immature rabbit fetuses infected with aerosolised GBS. ${ }^{4}$ In addition, decreased phagocytosis and a diminished release of cytokines, neutrophil elastase, and oxygen metabolites have been described following in vitro incubation of phagocytes with surfactant. $^{56}$

Recently, we identified a GBS strain that is pathogenic to rabbits and developed an animal model to study the effect of surfactant in ventilated near-term newborn rabbits following intratracheal infection with GBS. ${ }^{7}$ However, in a clinical situation term newborn infants would rarely receive surfactant treatment for respiratory failure due to pneumonia, the main target group for surfactant replacement being premature infants with a combination of surfactant deficiency and pulmonary infection.

The present study aimed to evaluate the effect of surfactant treatment on lung function, inflammatory changes, and bacterial growth in immature ventilated newborn rabbits with experimentally induced neonatal GBS pneumonia.

\section{Methods}

BACTERIA

An abundantly encapsulated low density (LD) phase variant of bacteria was processed from the reference strain GBS 090 Ia Colindale by repeated gradient centrifugation (kind gift of Stellan Håkansson, University of Umeå, Sweden). Previous experience had indicated that the polysaccharide capsule is an important pathogenic factor in rabbits. ${ }^{8}$ GBS type Ia is a 
subtype commonly isolated from neonates with early onset group B streptococcal septicaemia; type III is commonly found in neonates with late onset disease, especially meningitis. The strain was stored in aliquots at $-70^{\circ} \mathrm{C}$, precultured, washed, centrifuged and suspended in physiological saline at a concentration of $10^{9}$ live bacteria per $\mathrm{ml}$. The number of colony forming units (cfu) in the stock suspension was determined for each individual experiment by serial dilution and bacterial counting on blood agar plates following a 24 hour incubation period at $37^{\circ} \mathrm{C}$ with $5 \% \mathrm{CO}_{2}$. Details of the procedure have been described elsewhere. ${ }^{7}$

SURFACTANT

Curosurf is a modified natural surfactant isolated from minced pig lungs. Neutral lipids, cholesterol, and lipid esters are removed by a combination of chloroform-methanol extraction and liquid-gel chromatography. It is sterilised by high pressure filtration through a micropore filter system and finally suspended at a concentration of $80 \mathrm{mg} / \mathrm{ml}$ of phospholipids. ${ }^{9}$ Apart from $99 \%$ polar lipids ( $35 \%$ dipalmitoylphosphatidylcholine), it contains about $1 \%$ of proteins. The watersoluble surfactant proteins SP-A and SP-D are removed by the extraction procedure; only the hydrophobic proteins SP-B and SP-C, which are of major importance for adequate surfactant function, are contained in the preparation. Curosurf is effective in vitro, in animal experiments, and in controlled randomised clinical trials for the treatment of respiratory distress syndrome (RDS). ${ }^{9}$

\section{ANIMAL EXPERIMENTS}

Preterm rabbit fetuses (New Zealand White) were delivered at a gestational age of 28 days by caesarean section. Term gestation in rabbits is 31 days. The animals were anaesthetised and underwent tracheotomy at birth, after which they were transferred to a warmed plethysmograph system, ${ }^{10}$ as described before. ${ }^{7}$ They were mechanically ventilated in parallel in sealed Plexiglass chambers with a common ventilator system (Servo 900 B, Siemens-Elema, Solna, Sweden) delivering $100 \%$ oxygen. The working (maximum) pressure was set at $50 \mathrm{~cm} \mathrm{H}_{2} \mathrm{O}$. The frequency was 40 per minute, the inspiration:expiration time ratio $1: 1$. No positive endexpiratory pressure (PEEP) was applied, as PEEP might mask differences in compliance due to variations in surfactant function. ${ }^{11}$ The peak inspiratory pressure was recorded with a pressure transducer (EMT 34) and individually adjusted for each animal to obtain a tidal volume of $8-10 \mathrm{ml} / \mathrm{kg}$ bodyweight. Tidal volume was recorded with a specially designed "Fleisch-tube," a differential pressure transducer (EMT 31), an integrator (EMT 32), an amplifier (EMT 41) and a recording system (Mingograf 81 ; all equipment, SiemensElema). The system was calibrated for each individual experiment and a linear calibration curve was obtained for tidal volumes between 0.1 and $0.8 \mathrm{ml}$. Lung-thorax compliance $\left(\mathrm{ml} / \mathrm{kg}\right.$. $\left.\mathrm{cm} \mathrm{H}_{2} 0\right)$ was calculated from the quotient of tidal volume (expressed in $\mathrm{ml} / \mathrm{kg}$ ) and peak inspiratory pressure (expressed in $\mathrm{cm}$ $\mathrm{H}_{2} \mathrm{O}$ ). All recordings were obtained at 0,15 , $30,45,60,90,120,150,180,210,240,270$ and 300 minutes. An electrocardiogram (ECG) was recorded at the same intervals and animals were counted as survivors if the heart rate was $>100$ per minute without evidence of arrhythmia or atrioventricular block.

At birth the animals were randomly allocated to the different treatment groups. At 15 minutes they received an intratracheal injection of either the GBS suspension or sterile $\mathrm{NaCl}$ $0.9 \%(5 \mathrm{ml} / \mathrm{kg})$. At 30 minutes, either surfactant (Curosurf, $2.5 \mathrm{ml} / \mathrm{kg}$ ) or again saline $(2.5 \mathrm{ml} / \mathrm{kg})$ was administered via the tracheal cannula. The experimental groups that originated from this procedure were as follows.

Animals infected with GBS and treated with either saline (GBS/NaCl) or Curosurf (GBS/ Curosurf) and animals treated initially with saline receiving saline again $(\mathrm{NaCl} / \mathrm{NaCl})$ or the same volume of Curosurf ( $\mathrm{NaCl} / \mathrm{Curosurf})$. The maximum period of ventilation was 300 minutes in all these animals. Animals in a fifth group were infected at 15 minutes with $5 \mathrm{ml} / \mathrm{kg}$ GBS and ventilated for 1 minute to move the instilled bacteria from the dead space to the periphery of the lungs. This group (GBS/1 min) served as a baseline for the evaluation of bacterial numbers and inflammatory changes. The GBS/ $\mathrm{NaCl}$ and the GBS/Curosurf groups were used for the direct evaluation of the effect of surfactant on bacterial proliferation. The saline group $(\mathrm{NaCl} / \mathrm{NaCl})$ served as a control group for comparison with the $\mathrm{NaCl} /$ Curosurf group, especially as regards the influence of surfactant on lung function.

At the end of the experiments the animals were killed by intracranial injection of xylocaine $0.5 \%$; the chest was opened with sterile instruments after the diaphragm had been examined for evidence of pneumothorax. Blood from the right cardiac ventricle was aspirated for a blood culture (Bactec Plus blood culture system, Becton Dickinson, Sparks, Maryland, USA). A sample anticoagulated with heparin was taken for blood gas analysis. The left lung was excised and cut into two halves in the sagittal plane. The peripheral part of the lung was weighed, placed immediately into the sterilised tube of a tissue homogeniser (Kontes Scientific Glassware instruments, Vineland, New Jersey, USA), and stored on ice until further processing. The medial part of the left lung was weighed and fixed for histological examination (see below). The right lung was used for biochemical studies not included in this report.

BACTERIAL COUNTING

The lung specimens were preprocessed with a pellet pestle dispenser (Kontes Scientific Glassware) and the weight of the sample was adjusted to $1 \mathrm{~g}$ with sterile $\mathrm{NaCl} 0.9 \%$. The lung was homogenised with a high speed (15000 rpm for 60 seconds) nylon microchamber tissue homogeniser (Sorval Omnimix, Dupont Instruments, Newton, Connecticut, USA). Lung homogenate $(0.5 \mathrm{ml})$ was sus- 
Table 1 Characterisation of animals in the experimental groups; values are mean (SD)

\begin{tabular}{|c|c|c|c|c|c|}
\hline \multirow[b]{2}{*}{ Parameter } & \multicolumn{5}{|l|}{ Experimental group } \\
\hline & GBS/1 minute $(n=14)$ & $\mathrm{GBS} / \mathrm{NaCl}(n=22)$ & GBS/Curosurf $(n=22)$ & $\mathrm{NaCl} / \mathrm{NaCl}(n=20)$ & $\mathrm{NaCl} /$ Curosurf $(n=20)$ \\
\hline Treatment 15 minutes & GBS $5 \mathrm{ml} / \mathrm{kg}$ & GBS $5 \mathrm{ml} / \mathrm{kg}$ & GBS $5 \mathrm{ml} / \mathrm{kg}$ & $\mathrm{NaCl} 5 \mathrm{ml} / \mathrm{kg}$ & $\mathrm{NaCl} 5 \mathrm{ml} / \mathrm{kg}$ \\
\hline Treatment 30 minutes & Sacrificed at 16 minutes & $\mathrm{NaCl} 2.5 \mathrm{ml} / \mathrm{kg}$ & Curosurf $2.5 \mathrm{ml} / \mathrm{kg}$ & $\mathrm{NaCl} 2.5 \mathrm{ml} / \mathrm{kg}$ & Curosurf $2.5 \mathrm{ml} / \mathrm{kg}$ \\
\hline Body weight (g) & $35 \quad(7)$ & $37 \quad(5)$ & $35 \quad(6)$ & $36 \quad(7)$ & $36 \quad(8)$ \\
\hline Left lung weight (g) & $0.40(0.11)$ & $0.32(0.08)$ & $0.35(0.09)$ & $0.31(0.07)$ & $0.34(0.09)$ \\
\hline Final survival time (minutes) & $16 \quad(0)$ & 184 & $174 \quad(105)$ & 189 & $(108)$ \\
\hline Heart rate (beats/minute) & $195 \quad(88)$ & $74 \quad(68)$ & 129 & 111 & (108) \\
\hline $\mathrm{pCO}_{2}(\mathrm{kPa})$ & 11.2 (3.6) & $8.3(4.1)$ & $7.5 \quad(2.9)$ & 7.5 (3.6) & $7.8 \quad(4.3)$ \\
\hline
\end{tabular}

pended and mixed thoroughly in tubes with 4.5 $\mathrm{ml}$ of sterile saline. A serial dilution was performed down to $10^{-9}$, and $100 \mu \mathrm{l}$ of the diluted bacterial suspensions were spread on blood agar plates. Colony counting was performed after 24 hour incubation, as described above. As bacterial proliferation follows a logarithmic growth curve the results were expressed as mean $\log _{10}$ cfu/g lung (wet weight).
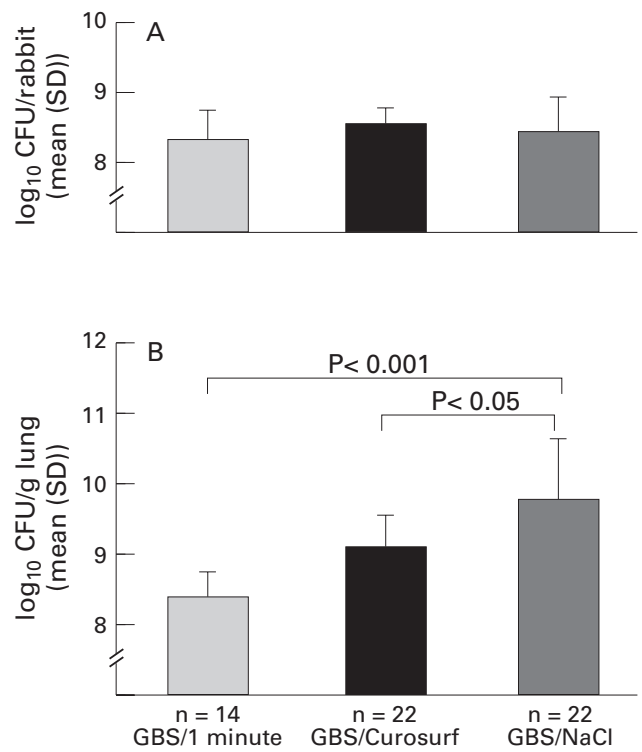

Figure 1 (A) Bacterial inoculum injected intratracheally in different study groups. (B) Bacterial proliferation at the end of the experiment. GBS/1 min animals represent the number of GBS at the beginning of the experiment ( $c f u=$ colony forming units).

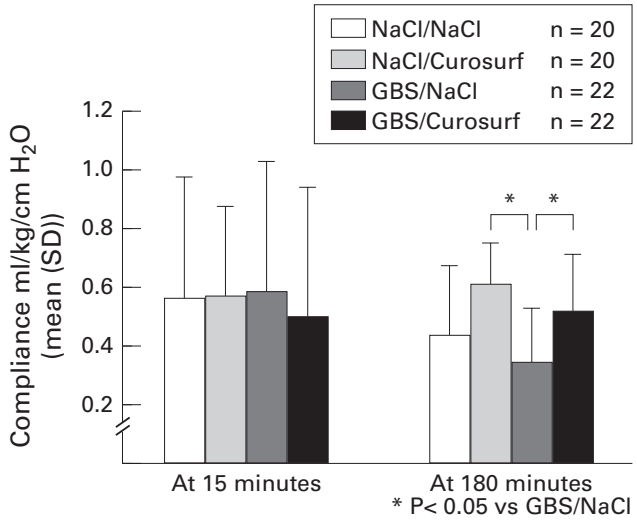

Figure 2 Lung-thorax compliance in different experimental groups at the beginning of the experiment (15 minutes) and after three hours of mechanical ventilation (180 minutes).
HISTOLOGICAL EXAMINATION OF THE LUNGS At the end of the experiment the medial part of the left lung was excised, fixed in formaldehyde $4 \%$, and subsequently embedded in paraffin wax. Transverse sections, stained with haematoxylin and eosin and Gram stain, were examined by light microscopy with special reference to the presence of intra-alveolar oedema, hyaline membranes, epithelial necrosis, bacterial proliferation and recruitment of inflammatory cells to the air spaces. The slides were coded so that the investigator was unaware of the experimental conditions of the individual animals.

STATISTICS

Data are given as mean (SD). Values for lung weight and physiological data were subjected to analysis of variance (ANOVA) using the CRISP software programme (Crunch Software, San Francisco, California, USA). Intergroup differences were evaluated using Student's and Newman-Keuls's tests. Differences in the incidence of complications between the groups were analysed using the $\chi^{2}$ test. The limit of significance was defined as $\mathrm{P}=0.05$.

The study design and the management of the animals complied with national legislation. The trial protocol was approved by the local committee for animal research.

\section{Results}

Ninety six fetuses were included in the data analysis. One animal per litter $(n=14)$ served as a control for bacterial growth at the beginning of the experiments (GBS/ $1 \mathrm{~min}$ ). Mean survival time was about 3 hours in all the other groups (table 1). Mean birthweight, left lung weight, final heart rate and $\mathrm{pCO}_{2}$ were not significantly different between the groups (table 1).

A similar dose of bacteria was given to all three infected groups at 15 minutes (fig 1A). Over the study period there was prominent bacterial proliferation in both the GBS infected groups treated with or without surfactant (fig 1B). However, significantly fewer bacteria were detected in the lungs of infected rabbits treated with surfactant than in those receiving saline at the same time point (fig 1B). All animals in the GBS/ $\mathrm{NaCl}$ and 21 of $22(95 \%)$ rabbits in the GBS/Curosurf group had GBS positive blood cultures at the end of the experiments.

At 15 minutes, no significant differences in compliance were found between the groups. Mean compliance was about $0.6 \mathrm{ml} / \mathrm{kg} . \mathrm{cm}$ $\mathrm{H}_{2} \mathrm{O}$, representing an intermediate level between values for very immature (gestational age 27 days) and near term (29.5 days) rabbits. 
The large SD indicates considerable variations in lung maturity among the animals (fig 2). Within three hours a substantial drop in compliance occurred in the $\mathrm{GBS} / \mathrm{NaCl}$ and the $\mathrm{NaCl} / \mathrm{NaCl}$ groups (fig 2). Infected animals not receiving surfactant had the lowest compliance values $(\mathrm{P}<0.05$ vs $\mathrm{GBS} / \mathrm{Curosurf}$ and $\mathrm{NaCl} /$ Curosurf). The highest compliance values were found in the $\mathrm{NaCl} /$ Curosurf group, indicating that some of these animals had surfactant deficiency based on lung immaturity and actually benefited from surfactant treat-

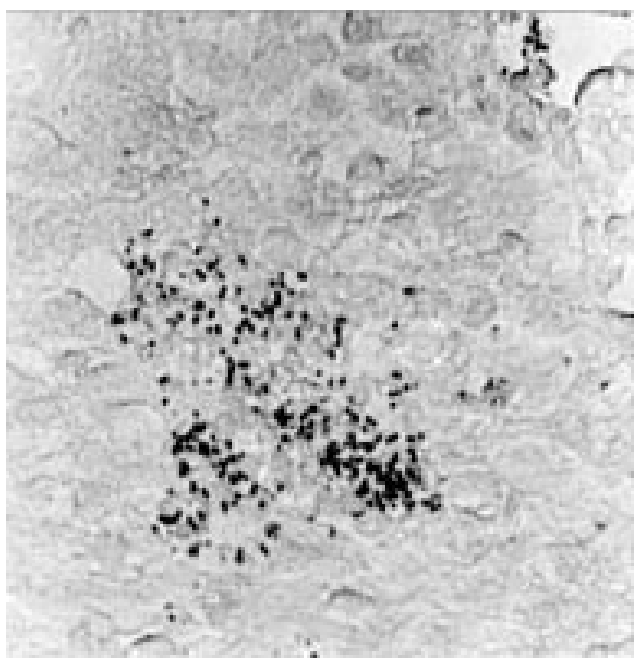

Figure 3 Histological lung section from an animal in the GBS/Cursosurf group, showing prominent bacterial proliferation. (Gram staining.)

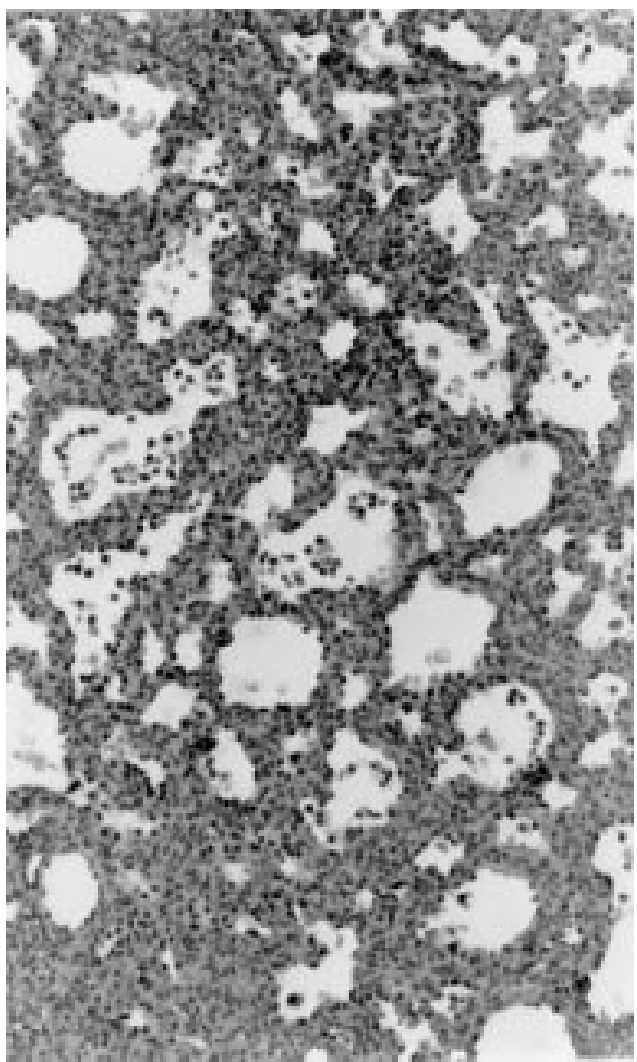

Figure 4 Histological lung section from an animal in the GBS/Curosurf group, showing uneven expansion and influx of phagocytes, especially neutrophils, into the alveolar spaces. (Haematoxylin and eosin.) ment (fig 2). In infected animals receiving surfactant the compliance was significantly ( $P$ $<0.05)$ improved compared with infected litter mate controls receiving saline (fig 2 ).

\section{HISTOLOGICAL FINDINGS}

In the GBS/1 min group there was a uniform alveolar expansion pattern corresponding to that of the fluid filled fetal lung. In one of these rabbits $(7 \%)$ a few phagocytic cells were present in the alveolar spaces; no inflammatory changes were found in the other animals. Few bacteria were detected by Gram staining. In contrast, prominent bacterial growth was found in the GBS infected groups ventilated for longer time periods (fig 3). Most of these lungs were unevenly expanded with epithelial necrosis, intra-alveolar oedema, and hyaline membrane formation. These findings were most prominent in the $\mathrm{GBS} / \mathrm{NaCl}$ group. The inflammatory response varied, ranging from virtually no influx of inflammatory cells to severe pneumonia (fig 4) in the GBS infected groups. A severe inflammatory response involving more than $30 \%$ of the lung parenchyma was found in four animals in the $\mathrm{GBS} / \mathrm{NaCl}$ group $(18 \%)$ as opposed to one in 22 rabbits $(5 \%)$ in the GBS/Curosurf group (not significant). In six of $20(30 \%)$ of the non-infected animals receiving saline at 15 minutes, a mild influx of inflammatory cells was noted. In none of these animals was more than $10 \%$ of the lung parenchyma involved in the inflammatory reaction.

\section{Discussion}

Our experimental model closely mimics the clinical situation in neonatal GBS infection. Significant bacterial proliferation associated with septicaemia could be induced in more than $90 \%$ of the infected animals. Although mean survival time ( 3 hours) was 2 hours shorter than in previous experiments on near-term rabbits, ${ }^{7}$ the number of bacteria detected per gram of lung homogenate was higher in the preterm rabbits than in the mature animals infected with the same dose. Sherman et al described similar results, indicating that bacterial proliferation occurred more rapidly in immature rabbit pups infected with aerosolised GBS than in mature ones. ${ }^{12}{ }^{13}$ These findings probably parallel the clinical situation. Necropsy findings from premature infants dying of GBS pneumonia often show overwhelming bacterial proliferation without a distinct inflammatory response. Similar to our results in the animal model, term newborn infants more often show bacterial proliferation that is accompanied by invasion of neutrophils into the lungs. ${ }^{14} 15$

In a clinical situation it is often difficult to differentiate between RDS based on surfactant deficiency due to lung immaturity alone and RDS triggered by GBS infection. ${ }^{3}$ Intraalveolar accumulation of leaking plasma proteins, bacterial degradation products, and substances released from neutrophils (such as oxygen free radicals, proteases including elastase) can result in a secondary surfactant dysfunction comparable with the acute respiratory distress syndrome (ARDS) seen in older 
patients. ${ }^{16}$ In the present study we found a mild influx of neutrophils in some of the ventilated animals that were not infected with GBS, suggesting a possible role for an inflammatory process in the pathogenesis of RDS in preterm infants with primary surfactant deficiency.

In our experiments the animals infected with GBS had the lowest compliance values after 3 hours of mechanical ventilation. The administration of surfactant could at least in part restore lung function. The large dose of surfactant $(200 \mathrm{mg} / \mathrm{kg}$ body weight) used in our experiments might be crucial in this context. We have recently shown, in an animal model of secondary surfactant dysfunction caused by experimental meconium aspiration, that an exogenous surfactant dose of 200 $\mathrm{mg} / \mathrm{kg}$ resulted in a significant and sustained improvement in oxygenation whereas a relapse was observed following a dose of $100 \mathrm{mg} / \mathrm{kg} .{ }^{17}$ Complete natural surfactants (human amniotic fluid surfactant, or surfactants prepared from lung lavage by sucrose gradient centrifugation) are probably superior in terms of resistance to surfactant inhibition. ${ }^{18}$ This can be attributed to the fact that these preparations contain larger amounts of SP-B and that the hydrophilic protein SP-A is present. In vitro data also indicate that SP-A and SP-D are important stimulants of macrophage function. ${ }^{19}$ Currently available surfactant preparations might therefore be suboptimal for treatment of congenital pneumonia.

However, SP-A seems to have a limited role in host defence against the "smooth" encapsulated phase variant of GBS used in our experiments. To stimulate phagocytosis this strain needs opsonisation by specific IgG antibodies. ${ }^{20} \mathrm{~A}$ "complete" natural porcine surfactant (containing SP-A and SP-D) prepared by lung lavage and sucrose gradient centrifugation did not enhance bacterial killing in GBS infected near-term rabbits when compared with Curosurf at the same dose of 100 $\mathrm{mg} / \mathrm{kg}$. ${ }^{21}$ Furthermore, inactivation of endogenous SP-A by a monoclonal anti-SP-A antibody ${ }^{22}$ in near-term GBS infected rabbits did not provoke changes in lung function or bacterial proliferation compared with an identical dose of non-specific IgG administered intratracheally immediately after birth. ${ }^{23}$

Data from clinical pilot studies ${ }^{24}{ }^{25}$ suggest that surfactant can be used successfully in neonates with congenital pneumonia but that the response to surfactant treatment is slower than in babies with uncomplicated RDS. ${ }^{16}$ Although initial data from animal experiments published by Sherman and coworkers indicated that it might be harmful to treat infected neonates with surfactant, ${ }^{4}$ the same group recently published an investigation showing that various commercially available modified natural surfactant preparations do not promote bacterial growth. ${ }^{12}$ In this study, using aerosolised streptococci in spontaneously breathing rabbit pups, the synthetic surfactant preparation Exosurf inhibited bacterial growth significantly. This is similar to our present data which show that surfactant treatment actually mitigates bacterial growth, perhaps by preventing atelectasis and accumulation of proteins in the alveoli. ${ }^{16}$ Keeping the airways open throughout the respiratory cycle is probably important for effective mucociliary clearance. Surfactant is also an important factor in fluid homeostasis of the neonatal lung. As the experimental animals were subjected to a considerable intratracheal fluid load postnatally, increased resorption of lung liquid might have contributed to the improved lung function observed in surfactant treated animals.

Data from other groups also indicate that surfactant might have an important role in the down-regulation of an inflammatory response in the lung. In recent experiments we observed a decreased release of reactive oxygen metabolites following incubation of neutrophils with Curosurf. ${ }^{20}$ In other experiments the tissue concentrations of neutrophilic elastase were significantly reduced in GBS infected nearterm rabbits treated with surfactant compared with infected controls receiving saline at the same time point. ${ }^{26}$ It has already been shown that the presence of free elastase activity in bronchial secretions of premature infants with RDS correlates with acute lung damage (pulmonary interstitial emphysema). ${ }^{27}$ Furthermore, elastase can cause proteolytic damage to SP-A and thereby elicit surfactant dysfunction. ${ }^{28}$ Similar data have been obtained using isolated neutrophils, indicating that surfactant might be important in limiting a secondary tissue damage mediated by neutrophils. This mechanism may be of special relevance in children and adults with acute respiratory failure due to pneumonia. Case reports and smaller clinical studies ${ }^{29}$ indicate that surfactant replacement might also be helpful in older patients with ARDS triggered by infection, ${ }^{30}$ and there are several experimental studies reporting improved lung function in animals with experimental bacterial, ${ }^{31}$ protozoal, ${ }^{32}$ or viral ${ }^{33}$ pneumonia treated with surfactant.

In conclusion, there is increasing evidence that apart from its well characterised biophysical properties, surfactant is of major importance in the lung defence system ${ }^{13}$ in both viral and bacterial infections. In our study we observed improved lung function and mitigation of bacterial growth following surfactant treatment in experimental neonatal GBS pneumonia in a preterm rabbit model. The present animal model should be useful for studies aiming at optimising strategies for treatment of congenital pneumonia, especially dose and timing of surfactant administration and efficacy and safety of new recombinant surfactant preparations.

The trial was supported by the Deutsche Forschungsgemeinschaft (DFG He 2072/2-1), the Swedish Medical Research Council (project No 3351), Konung Oscar II:s Jubileumsfond and the Research Funds of the Karolinska Institute.

We acknowledge the skilful work of Bim Linderholm, Eva Lundberg and Petru Popa.

1 Committee on Infectious Diseases and Committee on the Fetus and Newborn. Guidelines for prevention of group B
streptococcal (GBS) infection by chemoprophylaxis. Pedistreptococcal (GBS)
atrics $1992 ; 90: 775-8$. 
2 Weissman LE, Stoll BJ, Cruess DF, Hall RT, Merenstein $\mathrm{GB}$, Hemming VG, et al. Early onset group B-streptococcal sepsis: a current assessment. 7 Pediatr 1992;121:428-33.

3 Ablow R, Driscoll S, Effmann E, Gross I, Jolles CJ, Uauy R, et al. A comparison of early onset group B streptococcal neonatal infection and the respiratory distress syndrome. $N$ Engl f Med 1976;294:65-70.

4 Sherman MP, D'Ambola J, Aeberhard E, Barrett CT. Surfactant therapy of newborn rabbits impairs lung macrophage bactericidal activity. f Appl Physiol 1988;65:137-45.

5 Speer CP, Götze B, Curstedt T, Robertson B. Phagocytic function and TNF secretion of human monocytes exposed to natural porcine surfactant (Curosurf). Pediatr Res 1991;30:69-74.

6 Jarstrand C, Berggren P, Curstedt T, Johansson A, Robertson $\mathrm{B}$, Wienic A. Influence of lung surfactant phospholipson B, Wienic A. Influence of lung surfactant phospholip-
ids on neutrophilic granulocytes and blood monocytes. Prog Respir Res 1984;18:44-50.

7 Herting E, Jarstrand C, Rasool O, Curstedt T, Sun B, Robertson B. Experimental neonatal Group B streptococcal ertson B. Experimental neonatal Group B streptococcal pneumonia: effect of a modified porcine surfactant on bacterial proliferation in
Pediatr Res 1994;36:784-91.

8 Håkansson S, Berholm AM, Holm SE, Wagner B, Wagner $M$. Properties of high and low density subpopulations of group B streptococci: enhanced virulence of the low density variant. Microbiol Pathol 1988;5:345-55.

9 Collaborative European Multicenter Study Group. Surfactant replacement therapy for severe neonatal respiratory distress syndrome: an international randomized clinical trial. Pediatrics 1988;82:683-91.

10 Sun B, Kobayashi T, Curstedt T, Grossmann G, Robertson B. Application of a new ventilator-multi-plethysmograph system for testing efficacy of surfactant replacement in nystem for testing efficacy of surfactant rep

11 Rider ED, Jobe AH, Ikegami M, Sun B. Different ventilation strategies alter surfactant responses in preterm rabbits. $\mathscr{f}$ strategies alter surfactant resp

12 Sherman MP, Campbell LA, Merritt TA, Long WA, Gunkel $\mathrm{JH}$, Curstedt $\mathrm{T}$, et al. Effect of different surfactants on pulmonary group $\mathrm{B}$ streptococcal infection in premature (1)

13 Hall SL, Sherman MP. Intrapulmonary bacterial clearance of type III group B streptococcus is reduced in preterm compared with term rabbits and occurs independent of antibody. Am Rev Respir Dis 1992;145:1172-7.

14 Payne NR, Burke BA, Day DL, Christenson PC, Thompson TR, Ferrieri P. Correlation of clinical and pathologic findings in early onset neonatal Group B streptococcal infection with disease severity and prediction of outcome. Pediatr Infect Dis F 1988;7:836-47.

15 Katzenstein AL, Davis C, Braude A. Pulmonary changes in neonatal sepsis due to Group B $\beta$-hemolytic streptococcus: relation to hyaline membrane disease. $\mathcal{f}$ Infect Dis 1976;4:430-5.

16 Walther FJ. Surfactant therapy for neonatal lung disorders other than respiratory distress syndrome. In: Robertson B,
Taeusch HW, eds. Surfactant therapy for lung disease. New Taeusch HW, eds. Surfactant therapy for

17 Sun B, Herting E, Curstedt T, Robertson B. Exogenous surfactant improves lung compliance and oxygenation in adult rats with meconium aspiration. I Appl Physio 1994;77:1961-71.

18 Cockshutt AM, Weitz J, Possmayer F. Pulmonary surfactant-associated protein A enhances the surface activity of lipid extract surfactant and reverses inhibition by blood proteins in vitro. Biochemistry 1990;29:8424-9.
19 Van Iwaarden JF. Surfactant and the pulmonary defense system. In: Robertson B, van Golde LMG, Batenburg JJ, eds. Pulmonary Surfactant. From Molecular Biology to Clinical Practice. Amsterdam: Elsevier, 1993: 215-25.

20 Herting E, Jarstrand C, Rasool O, Curstedt T, Hakansson S, Robertson B. Effect of surfactant on nitroblue tetrazolium (NBT) reduction of polymorphonuclear leucocytes stimulated with type Ia group B streptococci. Acta Paediatr 1995;84:922-6.

21 Herting E, Jarstrand C, Curstedt T, Sun B, Calkovska A, Robertson B. Neonatal experimental group B streptococcal pneumonia: effects of gestational age, infectious dose and surfactant treatment on bacterial proliferation and inflammatory response. Applied Cardiopulmonary Pathoinflammatory response. Applied

22 Strayer DS, Herting E, Sun B, Robertson B. Antibody to surfactant protein A increases sensitivity of pulmonary surfactant to inactivation by fibrinogen in vivo. Am $\mathcal{f}$ Respir Crit Care Med 1996;153:1116-22.

23 Herting E, Strayer DS, Sun B, Robertson B. Influence of a monoclonal anti-SP-A antibody (R 5) on bacterial growth in term rabbits with experimental neonatal Group B streptococcal pneumonia. Biol Neonate 1996;69:217.

24 Auten RL, Notter RH, Kendig JW,Davis JM, Shapiro DL. Surfactant treatment of full-term newborns with respiratory failure. Pediatrics 1991;87:101-7.

25 Khammash H, Perlman $M$, Wojtulewicz J, Dunn $M$. Surfactant therapy in full-term neonates with severe respiratory failure. Pediatrics 1993;92:135-9.

26 Herting E, Speer CP, Sun B, Jarstrand C, Curstedt T, Robertson B. Einfluß von Surfactant auf pulmonales Entzündungsgeschehen und Elastase-Freisetzung bei ungsgeschehen und Elastase-Freisetzung bei Monatschr Kinderheilkd 1996;144:1319-25.

27 Speer CP, Reuss D, Harms K, Herting E, Gefeller O. Neutrophil elastase and acute pulmonary damage in neonates with severe respiratory distress syndrome. Pediatrics 1993;91:794-9.

28 Pison U, Tam EK, Caughey GH, Hawgood S. Proteolytic inactivation of dog lung surfactant-associated proteins by
neutrophil elastase. Biochim Biophys Acta 1989;92:251-7.

29 Walmrath D, Günther A, Ghofrani HA, Schermuly R, Schneider T, Grimminger F, et al. Bronchoscopic surfactant administration in patients with severe adult respiratory distress syndrome and sepsis. Am F Respir Crit Care Med 1996;154:57-62.

30 McCormack FX, Mason RJ. Surfactant therapy for adult respiratory distress syndrome. In: Robertson B, Taeusch HW, eds. Surfactant therapy for lung disease.New York: Marcel Dekker, 1995: 573-600.

31 Song GW, Robertson B, Curstedt T, Gan XZ, Huang WX. Surfactant treatment in experimental Escherichia coli pneumonia. Acta Anaesthesiol Scand 1996;40:1152-9.

32 Eijking EP, van Daal GJ, Tenbrinck R, Luijendijk A, Sluiters $\mathrm{JF}$, Hannappel E, et al. Effect of surfactant replacement on Med 1991;17:475-8.

33 Van Daal GJ, So KL, Gommers D, Eijking EP, Fiévez RB, Sprenger MJ, et al. Intratracheal surfactant administration restores gas exchange in experimental adult respiratory restores gas exchange in experimental adult respiratory Analg 1991;72:589-95.

34 Van Daal GJ, Bos JAH, Eijking EP, Gommers D, Hannappel E, Lachmann B. Surfactant replacement therapy improves pulmonary mechanics in end-stage influenza A pneumonia in mice. Am Rev Respir Dis 1992;145:859-63. 